\title{
Synthesis and structural characterization of the complexes of 2-(menthoxycarbonyl)ethyltin chloride
}

https://doi.org/10.1515/mgmc-2019-0003

Received July 29, 2018; accepted December 11, 2018.

Abstract: The complexes of 2-(menthoxycarbonyl)ethyltin chloride, $\mathrm{MenOCOCH}_{2} \mathrm{CH}_{2} \mathrm{SnCl}_{3} \cdot \mathrm{L}$ (Men $=$ Menthyl, $\mathrm{L}$ = benzyl phenyl sulfoxide (bpSO), 1; 2,2'-bipyridine (bpy), 2; 1,10-phenanthroline (phen), 3) and $\left[\mathrm{MenOCOCH} \mathrm{CH}_{2} \mathrm{SnCl}_{2}\left(\mathrm{OCH}_{3}\right)\right]_{2}(4)$, have been synthesized and characterized by means of elemental analysis, FT-IR, NMR $\left({ }^{1} \mathrm{H},{ }^{13} \mathrm{C}\right.$ and $\left.{ }^{119} \mathrm{Sn}\right)$ spectra. The crystal structures of 1, 3 and 4 have been determined by single crystal X-ray diffraction. The tin atoms in 1-4 are all hexa-coordinated. The tin atom in $\mathbf{1}$ adopts a distorted $\left[\mathrm{CSnCl}_{3} \mathrm{O}_{2}\right]$ octahedral geometry with an oxygen atom of the ligand and an intramolecular coordination of the oxygen atom from the carbonyl group to the tin atom. Complex $\mathbf{3}$ possesses a distorted $\left[\mathrm{CSnCl}_{3} \mathrm{~N}_{2}\right]$ octahedral geometry with two nitrogen atoms of a chelating phen ligand. The carbonyl oxygen atom of the ester moiety is not coordinating. Compound 4 is a centrosymmetric dimer with a four-membered $\mathrm{Sn}_{2} \mathrm{O}_{2}$ ring, and the tin atom has a distorted $\left[\mathrm{CSnCl}_{2} \mathrm{O}_{3}\right]$ octahedral geometry with an intramolecular $\mathrm{C}=\mathrm{O} \rightarrow \mathrm{Sn}$ coordination and intermolecular methoxy bridging.

Keywords: organotin; crystal structure; 2,2'-bipyridine; 1,10-phenanthroline 2-(menthoxycarbonyl)ethyltin

\section{Introduction}

The Lewis acid strengths of the organotin chlorides $\mathrm{R}_{n} \mathrm{SnCl}_{(4-n)}(n=1-3)$ decrease as $n$ increases. When $n=2$ or

\footnotetext{
* Corresponding author: Laijin Tian and Xicheng Liu, Key Laboratory of Natural Products and Pharmaceutical Intermediates, Qufu Normal University, Qufu 273165, China; Institute of Anticancer Agents Development, Qufu Normal University, Qufu 273165, China, e-mail: laijintian@163.com (Laijin Tian); chemlxc@163.com (Xicheng Liu).

Yichao Lin, Minghui Guo and Jin Liu, Key Laboratory of Natural Products and Pharmaceutical Intermediates, Qufu Normal University, Qufu 273165, China
}

1, five- or six-coordinate complexes with Lewis bases, such as $\mathrm{N}$ - and O-donor ligands, are usually formed via both inter- and intramolecular interactions (Davies, 2004). 2-Alkoxycarbonylethyltin trichlorides, $\mathrm{ROCOCH}_{2} \mathrm{CH}_{2} \mathrm{SnCl}_{3}$, are functionally substituted alkyltin chlorides, and are readily available from the reactions of $\mathrm{CH}_{2}=\mathrm{CHCOOR}$ with $\mathrm{SnCl}_{2}$ and $\mathrm{HCl}$ (Hutton et al., 1978). These compounds have received considerable attention because of the variety of coordination geometries regarding the tin atom (de Morais et al., 2017; Harrison et al., 1979; Howie and Wardell, 2002; Lima et al., 2009; Tian et al., 2005; Tian et al., 2016). Crystal structure determinations and spectra data (Balasubramanian et al., 1997; Buchanan, et al., 1996; Harrison et al., 1979; Howie and Wardell, 2002; Lima et al., 2009; Liu et al., 2015; Maughan et al., 1981; Tian et al., 2005) have shown that the $\mathrm{ROCOCH}_{2} \mathrm{CH}_{2}$ unit is a $\mathrm{C}, \mathrm{O}$-chelating ligand by the intramolecular coordination of the carbonyl oxygen atom to the tin atom. However, the coordination can be broken and replaced by the other $\mathrm{N}$ and $\mathrm{O}$ donors (Balasubramanian et al., 1997; Buchanan, et al., 1996; de Morais et al., 2017; Maughan et al., 1981; Tian et al., 2016). In order to continue to expand the structural chemistry of functionalalkyltin chlorides, werecently reported thecrystal structure of the complexes of 2-(methoxycarbonyl)ethyltin trichloride with HMPA (hexamethylphosphoryltriamide) and phen (Guo et al., 2017). 2-(Menthoxycarbonyl)ethyltin trichloride containing an optically active menthyl group is a potential Lewis acid chiral catalyst, and the reaction with the Lewis base has been not investigated. Herein, we report the synthesis and characterization of the complexes formed by the reaction of $\mathrm{MenOCOCH}_{2} \mathrm{CH}_{2} \mathrm{SnCl}_{3}$ with bpSO, bipy, phen, or py (pyridine) in the methanol.

\section{Results and discussion}

\subsection{Synthesis}

Complexes 1-4 were prepared by the reactions of 2-(menthoxycarbonyl)ethyltin trichloride with the ligand bpSO, bpy, phen or py in 1:1 molar ratio in methanol. 


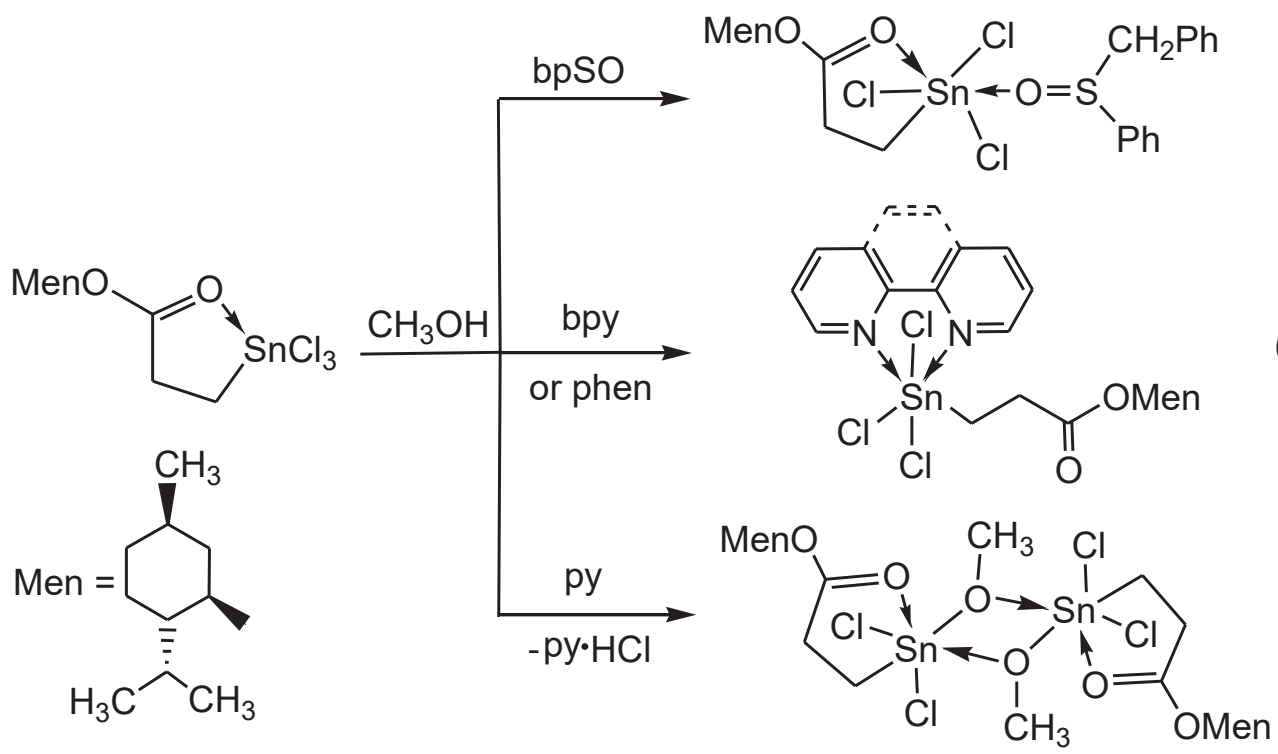

Scheme 1: Synthesis of the complexes 1 - 4.

When py was used, the expected complex MenOCOCH $\mathrm{CH}_{2} \mathrm{SnCl}_{3}$. py was not obtained, and compound 4, a methoxide of 2-(menthoxycarbonyl)ethyltin trichloride, was generated (Scheme 1). The complexes are colorless crystalline, and can be dissolved in common organic solvents such as chloroform, methanol, and acetone.

\subsection{Spectroscopic analysis}

In the IR of 2-(menthoxycarbonyl)ethyltin trichloride, the stretching vibration absorption of intramolecularly coordinated carbonyl is at $1645 \mathrm{~cm}^{-1}$. In $\mathbf{1 - 4}$, this band appears at $1645,1719,1730$, and $1648 \mathrm{~cm}^{-1}$, respectively, indicating that the $\mathrm{C}=\mathrm{O} \rightarrow \mathrm{Sn}$ coordination is maintained in $\mathbf{1}$ and $\mathbf{4}$ and is broken to accommodate two nitrogen atoms of the chelate ligands in $\mathbf{2}$ and $\mathbf{3}$. Considerable changes are observed for the ligand vibrations in 1-3. In 1, the $v(\mathrm{~S}=0)$ at $1035 \mathrm{~cm}^{-1}$ in the free bpSO is shifted to $955 \mathrm{~cm}^{-1}$, and the decreased value can be attributed to the complex formation with tin (Howie et al., 2012; Maughan et al., 1981). In free bpy molecule, the $v(\mathrm{C}=\mathrm{N})$ and $v(\mathrm{C}=\mathrm{C})$ (ring stretching vibrations) are observed at 1570 and 1420 $\mathrm{cm}^{-1}$. New bands are observed at 1601 and $1446 \mathrm{~cm}^{-1}$ in 2 as a result of complex formation. The out-of-plane $\mathrm{C}-\mathrm{H}$ bending vibration at $750 \mathrm{~cm}^{-1}$ in free ligand appears at 778 and $729 \mathrm{~cm}^{-1}$ in 2, indicating the bidentate nature of the ligand (Garad et al., 1981). Similar behavior is observed in phen complex 3.

In $\mathrm{CHCl}_{3}$ solution (ca. $0.02 \mathrm{~mol} / \mathrm{L}$ ), IR absorption frequency of carbonyl $(\mathrm{C}=0)$ in $\mathbf{1 - 4}$ is almost the same as in the solid, and is respectively observed at 1649,1720 ,
1724 , and $1652 \mathrm{~cm}^{-1}$, indicating that in the solution the intramolecular coordination of carbonyl to tin atom still exists in $\mathbf{1}$ and $\mathbf{4}$, and the carbonyl is free in $\mathbf{2}$ and $\mathbf{3}$.

The assignment of NMR for $\mathbf{1 - 4}$ was achieved by examining their chemical shift values, integration values and multiplicity patterns and also by careful comparison of NMR data with the related compounds reported earlier, such as $\mathrm{MenOCOCH}_{2} \mathrm{CH}_{2} \mathrm{SnCl}_{3}$ (Tian et al., 2005), $\mathrm{CH}_{3}$ COOMen (Lu et al., 2016), bpSO (Wang et al., 2018), $\left[\mathrm{Ru}(\mathrm{bpy})_{2}\left\{4,4^{\prime}\right.\right.$-bpy $\left.\left.(\mathrm{COOH})_{2}\right\}\right]\left(\mathrm{PF}_{6}\right)_{2}$ (Wang et al., 1999), and $\left(p-\mathrm{CH}_{3} \mathrm{C}_{6} \mathrm{H}_{4} \mathrm{CH}_{2}\right)_{2} \mathrm{SnCl}_{2}$.phen (Chandrasekar et al., 2015) (see experimental section). The ${ }^{1} \mathrm{H}$ and ${ }^{13} \mathrm{C}$ NMR data also support the presence of $\mathrm{C}=\mathrm{O} \rightarrow \mathrm{Sn}$ coordination in 1 and 4. The proton resonance of $-\mathrm{OCH}-(\mathrm{H}-4)$ in the substrate, 1 and $\mathbf{4}$ that appeared at $\sim 5.0 \mathrm{ppm}$ shows a downfield shift by $\sim 0.3 \mathrm{ppm}$ compared with that of $\mathbf{2}$ and 3 , and the $\delta\left({ }^{13} \mathrm{C}\right)$ values of $\mathrm{C}=\mathrm{O}(\mathrm{C}-3)$ and $-\mathrm{OCH}-(\mathrm{C}-4)$ in the substrate, $\mathbf{1}$ and $\mathbf{4}$ are deshielded by $\sim 8 \mathrm{ppm}(\mathrm{C}-3)$ and $\sim 5 \mathrm{ppm}$ (C-4), respectively, relative to those of 2 and 3. The $\mathrm{C}=\mathrm{O} \rightarrow \mathrm{Sn}$ coordination in the substrate, $\mathbf{1}$ and $\mathbf{4}$ causes the deshielding of the ${ }^{1} \mathrm{H}$ and ${ }^{13} \mathrm{C}$ nuclei of the $-\mathrm{CHOC}=\mathrm{O}$ moiety. However, when the coordination is broken by an external ligand (bpy and phen), the shielding of $-\mathrm{CHOC}=\mathrm{O}$ is recovered again. In complex $\mathbf{2}$, the chemical environment of two pyridine rings from the ligand bpy is different due to the rigid chelate ring formed by bpy coordination to the tin atom, so that the pyridine ring displays two sets of ${ }^{1} \mathrm{H}$ and ${ }^{13} \mathrm{C}$ NMR signals (Tian et al., 2018; Van Koten and Noltes, 1976; Wang et al., 1999). The same behavior is also found in phen complex 3 . The formation of the complexes is further confirmed by the changes of chemical shifts of the ligands. For example, the $\delta\left({ }^{1} \mathrm{H}\right)$ value of $\mathrm{H}-6^{\prime}\left(\mathrm{H}-6^{\prime \prime}\right)$ at 
$8.59 \mathrm{ppm}$ in free bpy shifts to 9.24 (H-6') and 9.90 (H-6") ppm in 2, and the $\delta\left({ }^{1} \mathrm{H}\right)$ value of $\mathrm{H}-2 \mathrm{a}(\mathrm{H}-2 \mathrm{~b})$ at $9.18 \mathrm{ppm}$ in free phen shifts to $9.61(\mathrm{H}-2 \mathrm{a})$ and $10.22(\mathrm{H}-2 \mathrm{~b}) \mathrm{ppm}$ in 3.

The ${ }^{119} \mathrm{Sn}$ chemical shifts $(\delta)$ primarily depend on the coordination number and the nature of the donor atom directly bound to the central tin atom. It has been reported that the $\delta$ values from +200 to $-60 \mathrm{ppm}$ for fourcoordinated, -90 to $-190 \mathrm{ppm}$ for five-coordinated and -210 to $-400 \mathrm{ppm}$ for six-coordinated tin atoms in solution (Holecek et al., 1986). The complexes 1-4 exhibit a single ${ }^{119} \mathrm{Sn}$ resonance at $-332.6,-278.3,-293.7$ and $-364.5 \mathrm{ppm}$, respectively, which fall well within the range proposed for six-coordinate tin centres (Airapetyan et al., 2015; Holecek et al., 1986). Thus, the tin atoms in these complexes have six-coordinate environments in $\mathrm{CDCl}_{3}$ solution, and it is suggested that compound $\mathbf{4}$ is an oxygen-bridged dimer in solution (see below X-ray analysis).

\subsection{Crystal structure analysis}

The molecular structures of $\mathbf{1}, \mathbf{3}$, and $\mathbf{4}$ are shown in Figures 1-4. The selected bond lengths and bond angles are listed in Table 1. Complex 1 crystallizes in chiral space group $P 2_{1} 2_{1} 2_{1}$ and is a discrete molecule with no close intermolecular contacts (Figure 1). The complex contains a five-membered chelate ring formed via intramolecular $\mathrm{C}=\mathrm{O} \rightarrow \mathrm{Sn}$ coordination. The tin atom is hexa-coordinated with the coordinating atoms $\mathrm{C}(1), \mathrm{Cl}(1), \mathrm{C} 1(2), \mathrm{Cl}(3)$, $\mathrm{O}(1)$ and $\mathrm{O}(2)$ in a distorted octahedral arrangement. The distortion from ideal octahedral geometry is expressed by $\mathrm{C}(1)-\mathrm{Sn}(1)-\mathrm{Cl}(3), \mathrm{O}(2)-\mathrm{Sn}(1)-\mathrm{Cl}(2)$ and $\mathrm{O}(1)$ Sn(1)-C1(1) angles of 156.89(19), 172.72(11) and 174.43(12) ${ }^{\circ}$, respectively, deviating from $180^{\circ}$. The interatomic $\mathrm{Sn}(\mathrm{l})$ $\mathrm{O}(2)$ distance of 2.403(4) $\AA$ ) is similar to 2.397(7) Å reported for $\mathrm{MenOCOCH}_{2} \mathrm{CH}_{2} \mathrm{SnCl}_{3}$ (Tian et al., 2005). The $\mathrm{Sn}(1)$ $\mathrm{O}$ (1) distance of 2.259(4) $\AA$ is obviously shorter than $\mathrm{Sn}(1)$ $\mathrm{O}(2)(2.403(4) \AA$ ) , indicating a stronger $\mathrm{S}=\mathrm{O} \rightarrow \mathrm{Sn}$ than $\mathrm{C}=\mathrm{O} \rightarrow \mathrm{Sn}$ interaction (Maughan et al., 1981). In addition, the $\mathrm{Sn}(1)-\mathrm{O}(1)$ distance is also in agreement with that observed in other organotin sulfoxide complexes, such as $\mathrm{Ph}_{2} \mathrm{SnCl}_{2}\left[\left(\mathrm{PhCH}_{2}\right)_{2} \mathrm{SO}\right]_{2}(\mathrm{Sn}-\mathrm{O} 2.258(4) \AA ̊)$ (Sousa et al., 2009) and $\left[2-\left(\mathrm{Me}_{2} \mathrm{NCH}_{2}\right) \mathrm{C}_{6} \mathrm{H}_{4}\right] \mathrm{SnCl}_{3}\left[\left(\mathrm{CH}_{3}\right)_{2} \mathrm{SO}\right] \quad(\mathrm{Sn}-\mathrm{O}$ 2.253(2) $\AA$ ) (Varga etal., 2005). Compared with the S(1)-O(1) (1.501(4) A) in free bpSO (Fuller et al. 2009), the bond in 1 becomes longer (1.513(4) $\AA$ ), further confirming the formation of $\mathrm{S}=\mathrm{O} \rightarrow \mathrm{Sn}$ coordination. The $\mathrm{Sn}-\mathrm{Cl}$ distance lies in the range of 2.3320(18)-2.4310(19) $\AA$, and the $\mathrm{Sn}(1)-\mathrm{Cl}(1)$ bond involving the ligand $\mathrm{O}(\mathrm{l})$ atom trans to $\mathrm{Cl}(1)$ atom is the longest. The features are comparable with those found in $\mathrm{CH}_{3} \mathrm{OCOCH}_{2} \mathrm{CH}_{2} \mathrm{SnCl}_{3} \cdot \mathrm{O}=\mathrm{P}\left[\mathrm{N}\left(\mathrm{CH}_{3}\right)_{2}\right]_{3}$ (Guo et al., 2017), $\mathrm{H}_{2} \mathrm{NCOCH}_{2} \mathrm{CH}_{2} \mathrm{SnCl}_{3} \cdot \mathrm{O}=\mathrm{S}\left(\mathrm{CH}_{3}\right)_{2}$ (Howie et al., 2012).

Complex $\mathbf{3}$ crystallizes in the monoclinic space group $P 2_{1}$, and the asymmetric unit contains two independent molecules which do not differ from each other significantly (Figure 2). The central Sn atom exists in a

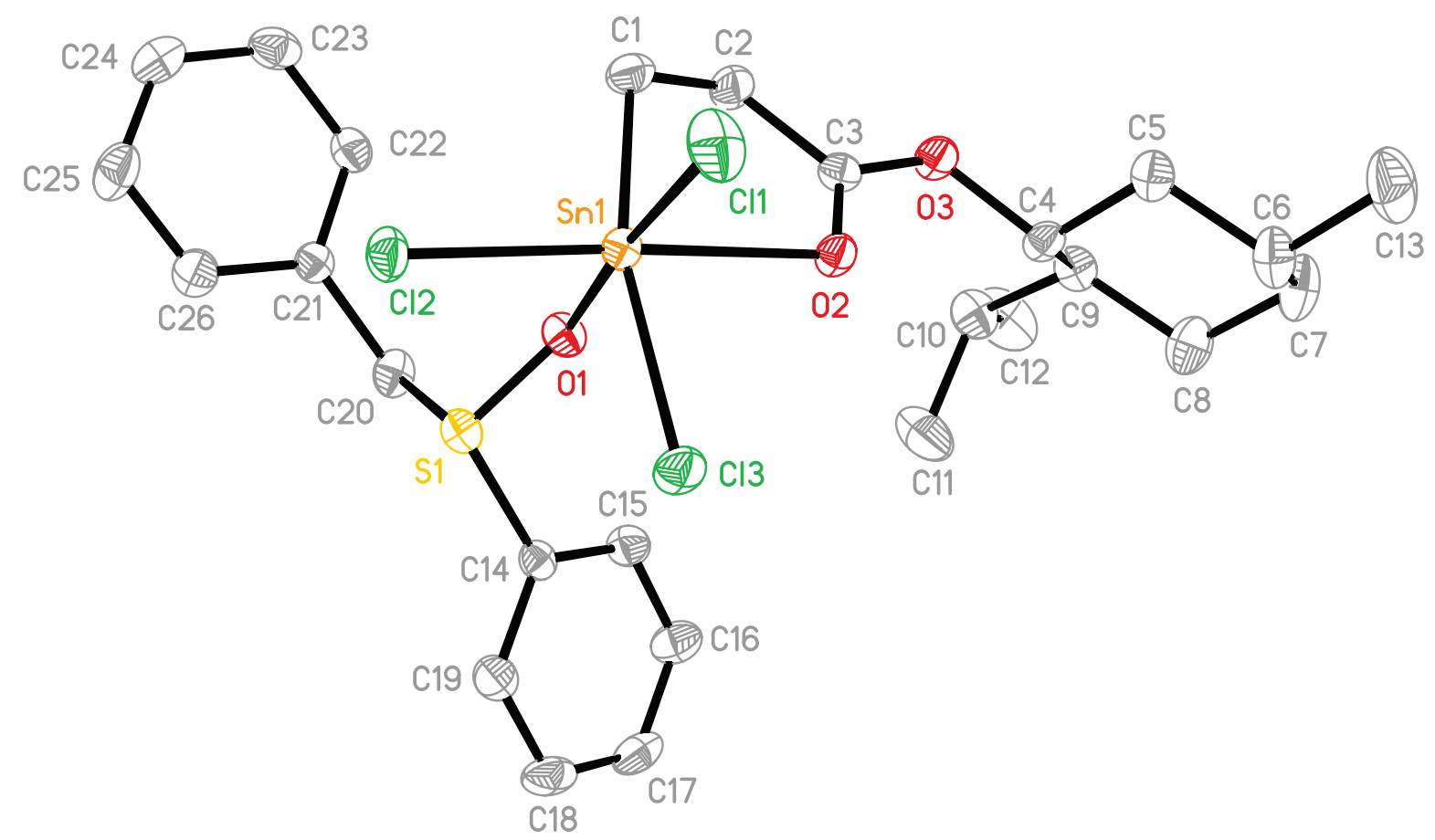

Figure 1: The molecular structure of 1. Ellipsoids are drawn at the $30 \%$ probability level. Hydrogen atoms are omitted for clarity. 


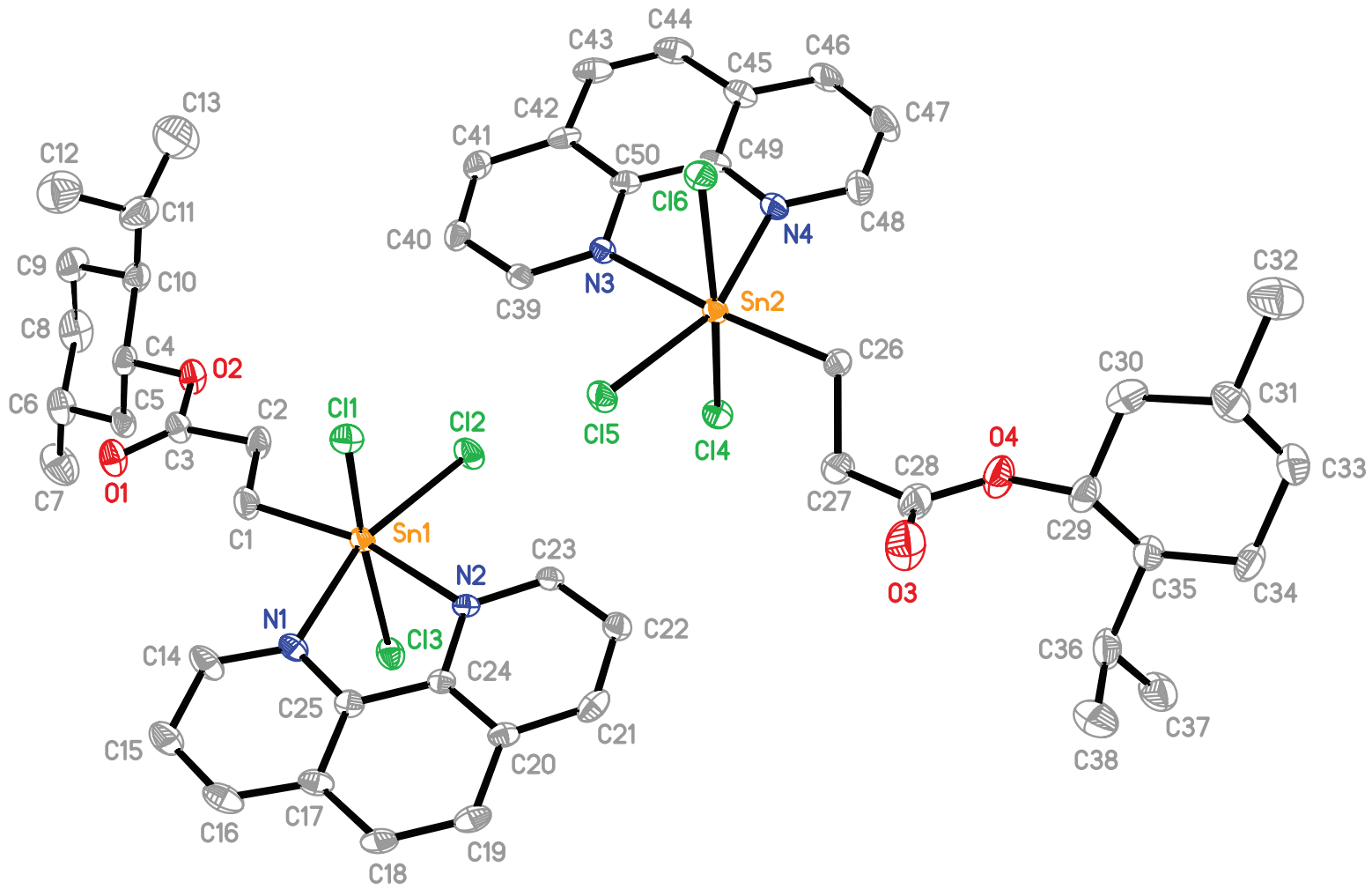

Figure 2: The molecular structure of 3. Ellipsoids are drawn at the $30 \%$ probability level. Chloroform and hydrogen atoms are omitted for clarity.

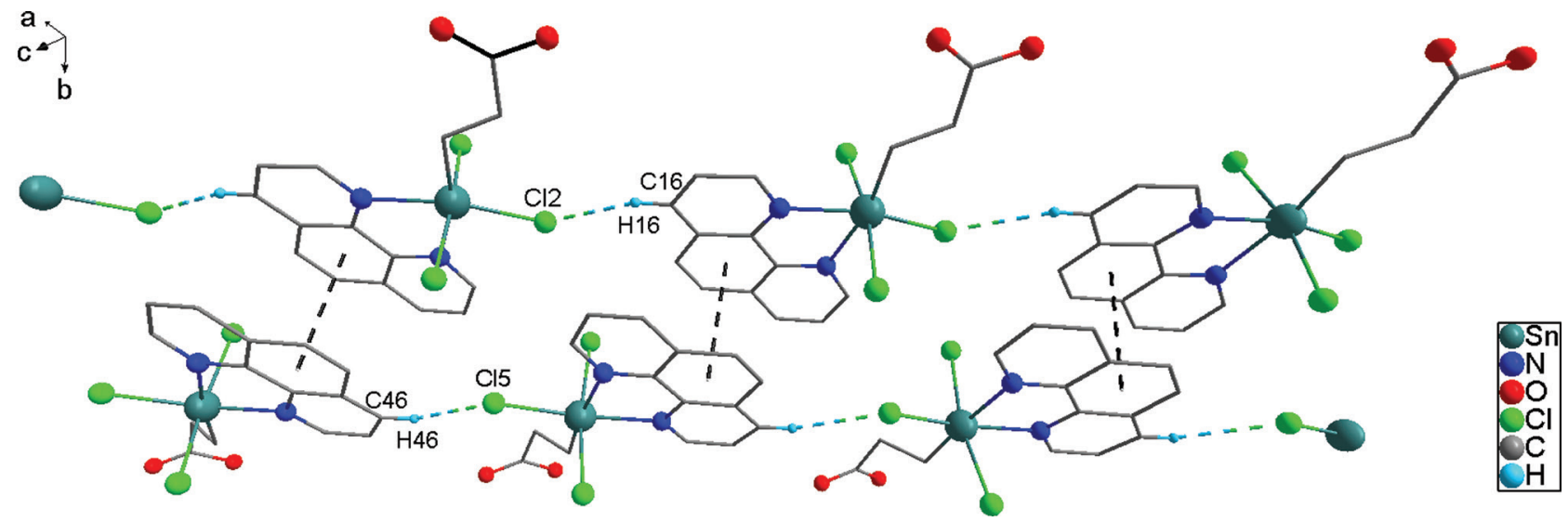

Figure 3: The 1D double-chain supramolecular architecture formed by intermolecular $\mathrm{C}-\mathrm{H} \cdots \mathrm{Cl}$ and $\pi-\pi$ stacking interactions. Menthyl and hydrogen atoms except $\mathrm{H} 16$ and $\mathrm{H} 46$ are omitted for clarity.

distorted octahedral geometry defined by a carbon atom of menthoxycarbonylethyl group, three $\mathrm{Cl}$ atoms and the two $\mathrm{N}$ atoms from a chelating phen ligand with the axial bond angles of 160.22(17)-173.5(3) ${ }^{\circ}$. The distortions from the ideal geometry may be rationalized by the restricted bite angle N(1)-Sn(1)-N(2) $\left(72.5(2)^{\circ}\right)$ and N(3)$\mathrm{Sn}(2)-\mathrm{N}(4)\left(73.0(2)^{\circ}\right)$ of the chelate ligand (Guo et al., 2017; Tian et al., 2016,). The five-membered chelate ring formed by the intramolecular $\mathrm{C}=\mathrm{O} \rightarrow \mathrm{Sn}$ coordination in the substrate $\mathrm{MenOCOCH} \mathrm{CH}_{2} \mathrm{SnCl}_{3}$ (Tian et al., 2005) has been broken and the carbonyl oxygen atom of the ester moiety is not coordinating $(\mathrm{Sn}(1) \cdots \mathrm{O}(1) 4.905 \AA$ and $\operatorname{Sn}(2) \cdots 0(3) 5.249(6) \AA ̊)$. The new five-membered chelate ring consisting of $\mathrm{N}(1), \mathrm{Sn}(1), \mathrm{N}(2), \mathrm{C}(24)$ and $\mathrm{C}(25)$ or $\mathrm{N}(3)$, $\mathrm{Sn}(2), \mathrm{N}(4), \mathrm{C}(49)$ and C(50) is essentially planar, and the maximum deviation from the mean plane is 0.049(3) $\AA$ for the $\operatorname{Sn}(1)$ atom and 0.033(3) $\AA$ for the $\operatorname{Sn}(2)$ atom, respectively. The $\mathrm{Sn}(1)-\mathrm{N}(2)$ (2.231(6) $\AA$ ) and $\mathrm{Sn}(2)-\mathrm{N}(3)$ 


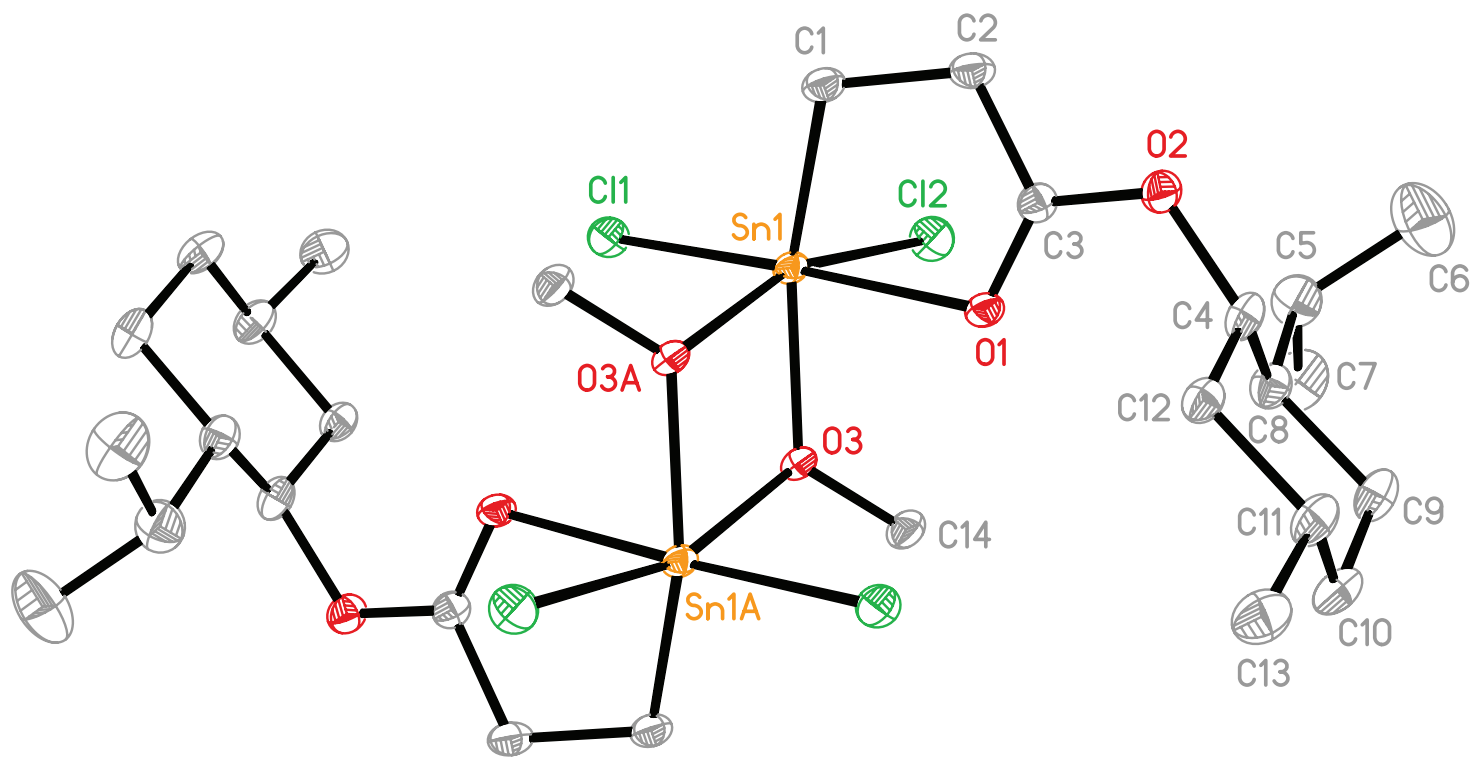

Figure 4: The molecular structure of 4. Ellipsoids are drawn at the $30 \%$ probability level. Hydrogen atoms are omitted for clarity. $A=-x,-y+1,-z+1$.

Table 1: Selected bond lengths $(\AA)$ and angles $\left(^{\circ}\right)$ for 1,3 and 4.

\begin{tabular}{|c|c|c|c|c|c|}
\hline \multicolumn{6}{|l|}{1} \\
\hline $\operatorname{Sn}(1)-0(1)$ & $2.259(4)$ & $\operatorname{Sn}(1)-C(1)$ & $2.135(7)$ & $\mathrm{Sn}(1)-\mathrm{Cl}(2)$ & $2.3855(15)$ \\
\hline $\mathrm{Sn}(1)-O(2)$ & $2.403(4)$ & $\mathrm{Sn}(1)-\mathrm{Cl}(1)$ & $2.4310(19)$ & $\mathrm{Sn}(1)-\mathrm{Cl}(3)$ & $2.3320(18)$ \\
\hline$C(1)-S n(1)-O(1)$ & $82.7(2)$ & $\mathrm{Cl}(3)-\mathrm{Sn}(1)-\mathrm{Cl}(2)$ & $97.26(7)$ & $C(1)-S n(1)-C l(1)$ & 96.3(2) \\
\hline $\mathrm{C}(1)-\mathrm{Sn}(1)-\mathrm{Cl}(3)$ & 156.89(19) & $C(1)-S n(1)-O(2)$ & $76.2(2)$ & $\mathrm{O}(1)-\mathrm{Sn}(1)-\mathrm{Cl}(1)$ & $174.43(12)$ \\
\hline $\mathrm{O}(1)-\mathrm{Sn}(1)-\mathrm{Cl}(3)$ & $86.11(12)$ & $O(1)-S n(1)-O(2)$ & $83.00(14)$ & $\mathrm{Cl}(3)-\mathrm{Sn}(1)-\mathrm{Cl}(1)$ & 92.80(9) \\
\hline $\mathrm{C}(1)-\mathrm{Sn}(1)-\mathrm{Cl}(2)$ & $102.9(2)$ & $\mathrm{Cl}(3)-\mathrm{Sn}(1)-\mathrm{O}(2)$ & $82.37(11)$ & $\mathrm{Cl}(2)-\mathrm{Sn}(1)-\mathrm{Cl}(1)$ & 95.83(7) \\
\hline $\mathrm{O}(1)-\mathrm{Sn}(1)-\mathrm{Cl}(2)$ & $89.73(11)$ & $\mathrm{Cl}(2)-\mathrm{Sn}(1)-\mathrm{O}(2)$ & $172.72(11)$ & $\mathrm{O}(2)-\mathrm{Sn}(1)-\mathrm{Cl}(1)$ & $91.44(11)$ \\
\hline \multicolumn{6}{|l|}{ 3. $\mathrm{CHCl}_{3}$} \\
\hline & $2.122(8)$ & $\mathrm{Sn}(1)-\mathrm{Cl}(2)$ & $2.4111(19)$ & $\operatorname{Sn}(2)-N(4)$ & $2.291(6)$ \\
\hline Sn(1)-C(1) & $2.286(5)$ & $\mathrm{Sn}(1)-\mathrm{Cl}(3)$ & $2.467(2)$ & $\mathrm{Sn}(2)-\mathrm{Cl}(5)$ & $2.4195(17)$ \\
\hline $\mathrm{Sn}(1)-\mathrm{N}(1)$ & $2.231(6)$ & $\operatorname{Sn}(2)-C(26)$ & $2.157(7)$ & $\mathrm{Sn}(2)-\mathrm{Cl}(4)$ & 2.4493(19) \\
\hline $\operatorname{Sn}(1)-N(2)$ & $2.450(2)$ & $\operatorname{Sn}(2)-N(3)$ & $2.256(6)$ & $\mathrm{Sn}(2)-\mathrm{Cl}(6)$ & $2.466(2)$ \\
\hline $\mathrm{Sn}(1)-\mathrm{Cl}(1)$ & $165.4(3)$ & $\mathrm{C}(1)-\mathrm{Sn}(1)-\mathrm{Cl}(3)$ & $94.0(3)$ & $N(4)-S n(2)-C I(5)$ & $160.22(17)$ \\
\hline$C(1)-S n(1)-N(2)$ & 92.9(3) & $N(2)-S n(1)-C l(3)$ & $84.51(15)$ & $C(26)-S n(2)-C l(4)$ & $95.5(2)$ \\
\hline$C(1)-S n(1)-N(1)$ & $72.5(2)$ & $\mathrm{N}(1)-\mathrm{Sn}(1)-\mathrm{Cl}(3)$ & $85.35(16)$ & $N(3)-S n(2)-C l(4)$ & $83.76(16)$ \\
\hline$N(2)-S n(1)-N(1)$ & $104.6(2)$ & $\mathrm{Cl}(2)-\mathrm{Sn}(1)-\mathrm{Cl}(3)$ & $90.29(8)$ & $\mathrm{N}(4)-\mathrm{Sn}(2)-\mathrm{Cl}(4)$ & 89.31(17) \\
\hline $\mathrm{C}(1)-\mathrm{Sn}(1)-\mathrm{Cl}(2)$ & 89.99(15) & $\mathrm{Cl}(1)-\mathrm{Sn}(1)-\mathrm{Cl}(3)$ & $168.56(8)$ & $\mathrm{Cl}(5)-\mathrm{Sn}(2)-\mathrm{Cl}(4)$ & $94.71(7)$ \\
\hline $\mathrm{N}(2)-\mathrm{Sn}(1)-\mathrm{Cl}(2)$ & $162.26(18)$ & $C(26)-S n(2)-N(3)$ & 173.5(3) & $C(26)-S n(2)-C I(6)$ & 94.2(2) \\
\hline $\mathrm{N}(1)-\mathrm{Sn}(1)-\mathrm{Cl}(2)$ & 95.6(3) & $C(26)-S n(2)-N(4)$ & $100.5(3)$ & $N(3)-\operatorname{Sn}(2)-\mathrm{Cl}(6)$ & $85.75(16)$ \\
\hline$C(1)-S n(1)-C l(1)$ & $84.64(15)$ & $N(3)-S n(2)-N(4)$ & $73.0(2)$ & $\mathrm{N}(4)-\mathrm{Sn}(2)-\mathrm{Cl}(6)$ & $81.77(17)$ \\
\hline $\mathrm{N}(2)-\mathrm{Sn}(1)-\mathrm{Cl}(1)$ & $87.96(16)$ & $C(26)-S n(2)-C I(5)$ & $98.4(2)$ & $\mathrm{Cl}(5)-\mathrm{Sn}(2)-\mathrm{Cl}(6)$ & 91.04(8) \\
\hline $\begin{array}{l}\mathrm{N}(1)-\mathrm{Sn}(1)-\mathrm{Cl}(1) \\
\mathrm{Cl}(2)-\mathrm{Sn}(1)-\mathrm{Cl}(1)\end{array}$ & $93.30(8)$ & $N(3)-\operatorname{Sn}(2)-C l(5)$ & $88.12(15)$ & $\mathrm{Cl}(4)-\mathrm{Sn}(2)-\mathrm{Cl}(6)$ & $167.86(7)$ \\
\hline \multicolumn{6}{|l|}{4} \\
\hline $\operatorname{Sn}(1)-0(1)$ & $2.367(3)$ & $\operatorname{Sn}(1)-O\left(3^{*) 1}\right.$ & $2.181(3)$ & $\mathrm{Sn}(1)-\mathrm{Cl}(2)$ & $2.3742(11)$ \\
\hline $\operatorname{Sn}(1)-0(3)$ & $2.048(3)$ & $\operatorname{Sn}(1)-C(1)$ & $2.147(4)$ & $\mathrm{Sn}(1)-\mathrm{Cl}(3)$ & $2.4013(12)$ \\
\hline$O(3)-S n(1)-C(1)$ & $152.16(15)$ & $O(3)^{\# 1-S n}(1)-O(1)$ & $88.84(10)$ & $\mathrm{O}(3)-\mathrm{Sn}(1)-\mathrm{Cl}(2)$ & 92.74(8) \\
\hline$O(3)-S n(1)-O(3)^{\# 1}$ & $70.59(11)$ & $\mathrm{O}(3)-\mathrm{Sn}(1)-\mathrm{Cl}(1)$ & $97.47(8)$ & $\mathrm{C}(1)-\mathrm{Sn}(1)-\mathrm{Cl}(2)$ & $99.54(14)$ \\
\hline$C(1)-S n(1)-O(3)^{\# 1}$ & $94.35(15)$ & $\mathrm{C}(1)-\mathrm{Sn}(1)-\mathrm{Cl}(1)$ & $106.10(12)$ & $\mathrm{O}(3)^{\# 1}-\mathrm{Sn}(1)-\mathrm{Cl}(2)$ & $163.04(8)$ \\
\hline$O(3)-S n(1)-O(1)$ & $80.27(10)$ & $\mathrm{O}(3)^{\# 1}-\mathrm{Sn}(1)-\mathrm{Cl}(1)$ & $90.20(8)$ & $\mathrm{O}(1)-\mathrm{Sn}(1)-\mathrm{Cl}(2)$ & $85.16(8)$ \\
\hline$C(1)-S n(1)-O(1)$ & $76.02(13)$ & $\mathrm{O}(1)-\mathrm{Sn}(1)-\mathrm{Cl}(1)$ & $177.73(7)$ & $\mathrm{Cl}(1)-\mathrm{Sn}(1)-\mathrm{Cl}(2)$ & $95.20(5)$ \\
\hline
\end{tabular}

Symmetry code \#1: $-x,-y+1,-z+1$. 
(2.256(6) Å) interatomic distances involving the $\mathrm{N}$ atom trans to $\mathrm{C}$ atom are shorter than the $\mathrm{Sn}(1)-\mathrm{N}(1)(2.286(5) \AA)$ and $\mathrm{Sn}(2)-\mathrm{N}(4)$ bonds (2.291(6) $\AA$ ) involving the $\mathrm{N}$ atom trans to $\mathrm{Cl}$ atom. The distances of six bonds around the tin atom are similar to those found in a closely related complex, $\mathrm{CH}_{3} \mathrm{OCOCH}_{2} \mathrm{CH}_{2} \mathrm{SnCl}_{3} \cdot$ phen (Guo et al., 2017). An arrangement of the $\mathrm{Cl}_{3} \mathrm{~N}_{2} \mathrm{C}$ donor atoms in complex 3 is not different from another analogue $\mathrm{C}_{6} \mathrm{H}_{5} \mathrm{CH}_{2} \mathrm{SnCl}_{3}$.phen (Hall and Tiekink, 1996). The tin-bound organic group is trans to a nitrogen atom in 3, while it is trans to a chlorine atom in $\mathrm{C}_{6} \mathrm{H}_{5} \mathrm{CH}_{2} \mathrm{SnCl}_{3}$.phen. Complex 3 is linked into a onedimensional double-chain supramolecular structure by intermolecular $\mathrm{C}-\mathrm{H} \cdots \mathrm{Cl}$ hydrogen bonds $\left(\mathrm{C}(16) \cdots \mathrm{Cl}(2)^{\# 1}\right.$ 3.61(1) $\AA, \mathrm{C}(16)-\mathrm{H}(16) \cdots \mathrm{Cl}(2)^{\# 1} 157.3^{\circ}$ and $\mathrm{C}(46) \cdots \mathrm{Cl}(5)^{\# 2}$ 3.65(2) $\AA, \mathrm{C}(46)-\mathrm{H}(46) \cdots \mathrm{Cl}(5)^{\# 1} 154.4^{\circ}$, symmetry code $\# 1: x+1, y, z+1$; \#2: $x-1, y, z-1)$ and $\pi-\pi$ stacking interactions between phenyl rings (dihedral angle $=1.14^{\circ}$ ) from phen ligand with the centroid-centroid separations of 3.540(2) $\AA$ (Glowka et al., 1999) (Figure 3).

Compound 4 exists as a centrosymmetric hexacoordinated dimerwithbridgingmethoxy groups(Figure4). Each tin atom is coordinated by two chlorine atoms occupying mutually cis-positions, a carbon atom and a carbonyl oxygen atom from the chelating $\mathrm{COCH}_{2} \mathrm{CH}_{2}$ moiety. The remaining positions in the distorted octahedral coordination geometry about each tin atom are occupied by two $\mu_{2}$-methoxy groups. The major distortions in the tin atom geometries may be traced to the acute angles induced by the $\mathrm{Sn}_{2} \mathrm{O}_{2}$ ring $\left(\mathrm{O}(3)-\mathrm{Sn}(1)-\mathrm{O}(3 \mathrm{~A}) 70.59(11)^{\circ}\right)$ and five-membered chelate $\mathrm{CSnO}$ ring (C(1)-Sn(1)-O(1) 76.02(13) $)^{\circ}$. The Sn-O distances within the $\mathrm{Sn}_{2} \mathrm{O}_{2}$ fourmembered ring are not symmetrical, with the bond trans to a carbon atom being shorter $(\mathrm{Sn}(1)-\mathrm{O}(3) 2.048(3) \AA)$ than that trans to a chlorine atom $(\mathrm{Sn}(1 \mathrm{~A})-\mathrm{O}(3)$ 2.181(3) $\AA$, symmetry code A: $-x,-y+1,-z+1)$, which is comparable with that found in $\left[\mathrm{H}_{2} \mathrm{NCOCH}_{2} \mathrm{CH}_{2} \mathrm{SnCl}_{2}\left(\mathrm{OCH}_{3}\right)\right]_{2}$ (Howie et al., 2011). The $\mathrm{Sn}(1)-\mathrm{O}(1)$ distance in the five-membered chelate ring is $2.367(3) \AA$, which is shorter than that (2.403(4) $\AA$ ) of the hexa-coordinated 1, indicating that the central tin atom in $\mathbf{4}$ has a stronger Lewis acidity.

\section{Conclusion}

Four new complexes of 2-(menthoxycarbonyl) ethyltin chloride, $\mathrm{MenOCOCH} \mathrm{CH}_{2} \mathrm{SnCl}_{3} \cdot \mathrm{L} \quad$ (1-3) and $\left[\mathrm{MenOCOCH} \mathrm{CH}_{2} \mathrm{SnCl}_{2}\left(\mathrm{OCH}_{3}\right)\right]_{2}$ (4), have been synthesized by the reaction of 2-(menthoxycarbonyl)ethyltin trichloride with pbSO, bpy, phen or py in methanol solution and characterized by NMR spectra and single crystal X-ray diffraction analysis. The tin atoms of the complexes are hexa-coordinated and adopt a distorted octrahedron geometry with $\left[\mathrm{CSnCl}_{3} \mathrm{O}_{2}\right],\left[\mathrm{CSnCl}_{3} \mathrm{~N}_{2}\right]$, and $\left[\mathrm{CSnCl}_{2} \mathrm{O}_{3}\right]$, respectively. Compounds 1-3 are molecular addition complexes, and $\mathbf{4}$ is a centrosymmetric dimer with a four-membered $\mathrm{Sn}_{2} \mathrm{O}_{2}$ ring. The intramolecular $\mathrm{C}=\mathrm{O} \rightarrow \mathrm{Sn}$ coordination still exists in $\mathbf{1}$ and $\mathbf{4}$, and has been replaced by the chelating bpy and phen ligands, respectively, leaving the carbonyl moieties non-coordinating in $\mathbf{2}$ and $\mathbf{3}$.

\section{Experimental}

\section{Materials and physical measurements}

2-(Menthoxycarbonyl)ethyltin trichloride was prepared according to the reported method (Tian et al., 2005). The other chemicals (Sinopharm Chemical Reagent Company Limited, Shanghai, China) were of reagent grade and were used without further purification. Carbon, hydrogen and nitrogen analyses were obtained using a Perkin Elmer 2400 Series II elemental analyzer (Perkin Elmer, Waltham, Massachusetts, USA). IR spectra were recorded on a Nicolet 470 FT-IR spectrophotometer using $\mathrm{KBr}$ discs in the range $4000-400 \mathrm{~cm}^{-1}$ (Thermo Nicolet Corporation, Madison, Wisconsin, USA). ${ }^{1} \mathrm{H}$ and ${ }^{13} \mathrm{C}$ NMR spectral data were collected using a Bruker Avance HD 500 NMR spectrometer (Bruker BioSpin, Switzerland) with $\mathrm{CDCl}_{3}$ as solvent and TMS as internal standard. ${ }^{119} \mathrm{Sn}$ NMR spectra were recorded in $\mathrm{CDCl}_{3}$ on a Varian Mercury Vx300 spectrometer using $\mathrm{Me}_{4} \mathrm{Sn}$ external reference (Varian Corporation, USA).

\section{Synthesis of the complexes}

A solution of 2-(menthoxycarbonyl)ethyltin trichloride $(0.872 \mathrm{~g}, 2 \mathrm{mmol})$ in methanol $(30 \mathrm{~mL})$ was added to the solutions of the ligand ( $2 \mathrm{mmol}$ ) (for bpSO, $0.432 \mathrm{~g}$; for bpy, $0.312 \mathrm{~g}$; for phen, $0.360 \mathrm{~g}$; for py, $0.158 \mathrm{~g}$ ) in methanol $(30 \mathrm{~mL})$ under stirring. The mixture was heated at reflux for $1 \mathrm{~h}$, and then the solution was concentrated under reduced pressure by a rotary evaporator. The residual solution was cooled to room temperature and filtered. The obtained solid was washed with cold methanol and dried in a vacuum dryer for $12 \mathrm{~h}$. The characterization data of the products are shown below (see Scheme 2):

\section{MenOCOCH $\mathrm{CH}_{2} \mathrm{SnCl}_{3} \cdot \mathrm{bpSO}$ (1)}

Yield $1.069 \mathrm{~g}(82 \%)$, m.p. $106-108^{\circ} \mathrm{C}$. Anal. Found: C, 47.23; $\mathrm{H}$, 5.19. Calc. for $\mathrm{C}_{26} \mathrm{H}_{35} \mathrm{Cl}_{3} \mathrm{O}_{3} \mathrm{SSn}$ : C, 47.84; H, 5.41\%. IR (KBr, 

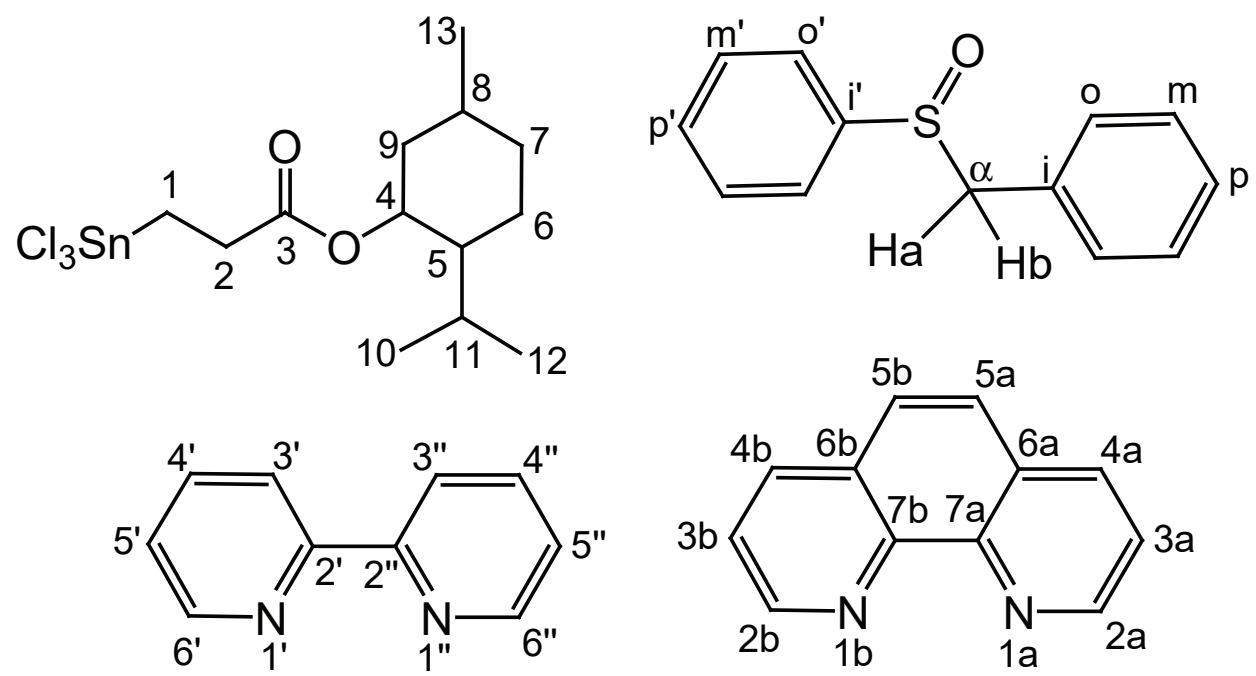

Scheme 2: The numbering scheme in 1-4 for the NMR assignment.

$\left.v, \mathrm{~cm}^{-1}\right): 1645(\mathrm{C}=0), 955(\mathrm{~S}=0) .{ }^{1} \mathrm{H} \mathrm{NMR}\left(\mathrm{CDCl}_{3}, d, \mathrm{ppm}\right): 0.71$ (d, $J=7.0 \mathrm{~Hz}, 3 \mathrm{H}, \mathrm{H}-13$ ), 0.84 (d, $J=7.0 \mathrm{~Hz}, 3 \mathrm{H}, \mathrm{H}-12$ ), 0.862.07 (m, 14H, H-1+H-5 H-11), 2.86 (t, $J=7.5 \mathrm{~Hz}, J\left({ }^{119 / 117} \mathrm{Sn}-{ }^{-1} \mathrm{H}\right)$ $=208 / 198 \mathrm{~Hz}, 2 \mathrm{H}, \mathrm{H}-2$ ), 4.15 (AB system, d, $J=12.5 \mathrm{~Hz}, 1 \mathrm{H}$, $\mathrm{H}-\mathrm{a}$ ), 4.31 (AB system, d, $J=12.5 \mathrm{~Hz}, 1 \mathrm{H}, \mathrm{H}-\mathrm{b}$ ), 4.97 (dt, $J=4.5$, $11.0 \mathrm{~Hz}, 1 \mathrm{H}, \mathrm{H}-4), 6.94(\mathrm{~d}, J=7.0 \mathrm{~Hz}, 2 \mathrm{H}, o-\mathrm{H}), 7.23(\mathrm{t}, J=7.5 \mathrm{~Hz}$, $2 \mathrm{H}, m-\mathrm{H}), 7.28-7.33\left(\mathrm{~m}, 3 \mathrm{H}, p-\mathrm{H}+o^{\prime}-\mathrm{H}\right), 7.43(\mathrm{t}, J=7.5 \mathrm{~Hz}$, $\left.2 \mathrm{H}, m^{\prime}-\mathrm{H}\right), 7.50\left(\mathrm{t}, J=7.5 \mathrm{~Hz}, 1 \mathrm{H}, p^{\prime}-\mathrm{H}\right) .{ }^{13} \mathrm{C}$ NMR $\left(\mathrm{CDCl}_{3}, d\right.$, ppm): 30.11 (C-1), $28.73\left(J\left({ }^{119 / 117} \mathrm{Sn}{ }^{13} \mathrm{C}\right)=78 \mathrm{~Hz}, \mathrm{C}-2\right), 181.66$ (C-3), 80.25 (C-4), 46.99 (C-5), 23.24 (C-6), 33.86 (C-7), 31.29 (C-8), 40.41 (C-9), 20.60 (C-10), 26.41 (C-11), 21.89 (C-12), 16.28 (C-13); 130.80 (i-C), 128.89 (o-C), 128.55 (m-C), 127.18 (p-C), $137.72\left(i^{\prime}-\mathrm{C}\right), 125.39\left(o^{\prime}-\mathrm{C}\right), 129.23\left(m^{\prime}-\mathrm{C}\right), 132.32\left(p^{\prime}-\mathrm{C}\right)$, $61.57(\alpha-C) .{ }^{119}$ Sn NMR $\left(\mathrm{CDCl}_{3}, d, \mathrm{ppm}\right):-332.6$.

\section{MenOCOCH $\mathrm{CH}_{2} \mathrm{SnCl}_{3} \cdot$ bpy (2)}

Yield 1.055 g (89\%), m.p. $194-1195^{\circ} \mathrm{C}$. Anal. Found: C, 46.65; $\mathrm{H}, 5.17, \mathrm{~N}$, 4.69. Calc. for $\mathrm{C}_{23} \mathrm{H}_{31} \mathrm{Cl}_{3} \mathrm{~N}_{2} \mathrm{O}_{2} \mathrm{Sn}$ : C, 46.62; H, 5.27; N, 4.73\%. IR (KBr, v, cm $\left.{ }^{-1}\right): 1719(\mathrm{C}=0), 1601,1446$ $(\mathrm{C}=\mathrm{N}+\mathrm{C}=\mathrm{C}) .{ }^{1} \mathrm{H}$ NMR $\left(\mathrm{CDCl}_{3}, d, \mathrm{ppm}\right): 0.74(\mathrm{~d}, J=7.0 \mathrm{~Hz}$, 3H, H-13), 0.83-2.02 (m, 15H, H-5 H-12), 2.43 (t, $J=7.5 \mathrm{~Hz}$, $\left.J\left({ }^{119 / 117} \mathrm{Sn}{ }^{-1} \mathrm{H}\right)=104 / 99 \mathrm{~Hz}, 2 \mathrm{H}, \mathrm{H}-1\right), 3.02(\mathrm{t}, J=7.5 \mathrm{~Hz}, J$ $\left.\left({ }^{119 / 117} \mathrm{Sn}^{-1} \mathrm{H}\right)=194 / 186 \mathrm{~Hz}, 2 \mathrm{H}, \mathrm{H}-2\right), 4.70(\mathrm{dt}, J=4.5,11.0 \mathrm{~Hz}$, 1H, H-4), 7.80 (t, $\left.J=6.5 \mathrm{~Hz}, 1 \mathrm{H}, \mathrm{H}-5^{\prime}\right), 7.88$ (t, $J=6.5 \mathrm{~Hz}, 1 \mathrm{H}$, $\left.\mathrm{H}-5^{\prime \prime}\right), 8.23\left(\mathrm{t}, J=7.5 \mathrm{~Hz}, 1 \mathrm{H}, \mathrm{H}-4^{\prime}\right), 8.30(\mathrm{t}, J=7.5 \mathrm{~Hz}, 1 \mathrm{H}$, H-4" $\left.4^{\prime \prime}\right) 8.42\left(\mathrm{~d}, J=8.0 \mathrm{~Hz}, 1 \mathrm{H}, \mathrm{H}-3^{\prime}\right), 8.46(\mathrm{~d}, J=8.0 \mathrm{~Hz}, 1 \mathrm{H}$, $\left.\mathrm{H}-3^{\prime \prime}\right), 9.24$ (d, $\left.J=5.0 \mathrm{~Hz}, 1 \mathrm{H}, \mathrm{H}-6^{\prime}\right), 9.90(\mathrm{~d}, J=5.0 \mathrm{~Hz}, 1 \mathrm{H}$, $\left.\mathrm{H}-6{ }^{\prime \prime}\right) .{ }^{13} \mathrm{C}$ NMR $\left(\mathrm{CDCl}_{3}, d\right.$, ppm): 31.31 (C-1), $30.63\left(J\left({ }^{119 / 117} \mathrm{Sn}-\right.\right.$ $\left.\left.{ }^{13} \mathrm{C}\right)=46 \mathrm{~Hz}, \mathrm{C}-2\right), 174.03$ (C-3), 74.48 (C-4), 47.01 (C-5), 23.38 (C-6), 34.25 (C-7), 31.43 (C-8), 40.90 (C-9), 20.84 (C-10),
26.06 (C-11), 22.06 (C-12), 16.36 (C-13); 145.34 (C-2'), 145. 98 (C-2"), $127.92\left(\mathrm{C}-3^{\prime}, \mathrm{C}-3^{\prime \prime}\right), 142.43\left(\mathrm{C}-4^{\prime}\right), 142.50\left(\mathrm{C}-4^{\prime \prime}\right), 123.02$ (C-5'), 123.17 (C-5'), 142.76 (C-6'), 143.25 (C-6" $\left.{ }^{\prime \prime}\right) .{ }^{119}$ Sn NMR $\left(\mathrm{CDCl}_{3}, d, \mathrm{ppm}\right):-278.3$.

\section{MenOCOCH $\mathrm{CH}_{2} \mathrm{SnCl}_{3} \cdot$ phen (3)}

Yield 1.048 g (85\%), m.p. $189-190^{\circ} \mathrm{C}$. Anal. Found: C, 48.79; H, 4.96, N, 4.49. Calc. for $\mathrm{C}_{23} \mathrm{H}_{31} \mathrm{Cl}_{3} \mathrm{~N}_{2} \mathrm{O}_{2} \mathrm{Sn}$ : C, 48.70; $\mathrm{H}, 5.07$; N, 4.54\%. IR (KBr, v, cm $\left.{ }^{-1}\right): 1730(\mathrm{C}=\mathrm{O}), 1523,1429$ $(\mathrm{C}=\mathrm{N}+\mathrm{C}=\mathrm{C}) .{ }^{1} \mathrm{H}$ NMR $\left(\mathrm{CDCl}_{3}, d, \mathrm{ppm}\right): 0.73(\mathrm{~d}, J=7.0 \mathrm{~Hz}$, 3H, H-13), 0.83-2.04 (m, 15H, H-5 H-12), 2.54 (t, $J=7.5 \mathrm{~Hz}$, $\left.J\left({ }^{119 / 117} \mathrm{Sn}-{ }^{-1} \mathrm{H}\right)=108 / 102 \mathrm{~Hz}, 2 \mathrm{H}, \mathrm{H}-1\right), 3.09(\mathrm{t}, J=7.5 \mathrm{~Hz}$, $\left.J\left({ }^{119 / 117} \mathrm{Sn}-{ }^{-1} \mathrm{H}\right)=196 / 185 \mathrm{~Hz}, 2 \mathrm{H}, \mathrm{H}-2\right), 4.72(\mathrm{dt}, J=4.5,11.0 \mathrm{~Hz}$, $1 \mathrm{H}, \mathrm{H}-4), 8.10$ (dd, $J=5.0,8.0 \mathrm{~Hz}, 1 \mathrm{H}, \mathrm{H}-3 \mathrm{a}), 8.15$ (dd, $J=$ 5.0, $8.0 \mathrm{~Hz}, 1 \mathrm{H}, \mathrm{H}-3 \mathrm{~b}$ ), 8.16 (s, 2H, H-5a+H-5b), 8.73 (d, $J=$ $8.0 \mathrm{~Hz}, 1 \mathrm{H}, \mathrm{H}-4 \mathrm{a}), 8.75$ (d, $J=8.0 \mathrm{~Hz}, 1 \mathrm{H}, \mathrm{H}-4 \mathrm{~b}), 9.61(\mathrm{~d}$, $J=5.0 \mathrm{~Hz}, 1 \mathrm{H}, \mathrm{H}-2 \mathrm{a}), 10.22(\mathrm{~d}, J=5.0 \mathrm{~Hz}, 1 \mathrm{H}, \mathrm{H}-2 \mathrm{~b}) .{ }^{13} \mathrm{C} \mathrm{NMR}$ $\left(\mathrm{CDCl}_{3}, d, \mathrm{ppm}\right): 31.17(\mathrm{C}-1), 30.60\left(J\left({ }^{119} \mathrm{Sn}^{13} \mathrm{C}\right)=46 \mathrm{~Hz}, \mathrm{C}-2\right)$, 174.12 (C-3), 74.46 (C-4), 47.02 (C-5), 23.37 (C-6), 34.26 (C-7), 31.43 (C-8), 40.90 (C-9), 20.83 (C-10), 26.05 (C-11), 22.05 (C-12), 16.35 (C-13); 145.83 (C-2a), 146.30 (C-2b), 126.04 (C-3a, C-3b), 134.18 (C-4a), 135.32 (C-4b), 127.56 (C-5a), 127.79 (C-5b), 129.81 (C-6a, C-6b), 140.92 (C-7a), 141.14 (C-7b). ${ }^{119} \mathrm{Sn}$ $\operatorname{NMR}\left(\mathrm{CDCl}_{3}, d, \mathrm{ppm}\right):-293.7$.

\section{$\left[\left(\mathrm{CH}_{3} \mathrm{O}\right) \mathrm{Cl}_{2} \mathrm{SnCH}_{2} \mathrm{CH}_{2} \mathrm{COOMen}\right]_{2}$ (4)}

Yield 0.518 g (60\%), m.p. $98-99^{\circ} \mathrm{C}$. Anal. Found: C, 38.74; $\mathrm{H}$, 5.89. Calc. for $\mathrm{C}_{14} \mathrm{H}_{26} \mathrm{Cl}_{2} \mathrm{O}_{3} \mathrm{Sn}: \mathrm{C}, 38.93 ; \mathrm{H}, 6.07 \%$. IR ( $\mathrm{KBr}$, 
Table 2: Crystallographic and refinement data of 1,3 and 4.

\begin{tabular}{|c|c|c|c|}
\hline Compound & 1 & $3 \cdot \mathrm{CHCl}_{3}$ & 4 \\
\hline Empirical formula & $\mathrm{C}_{26} \mathrm{H}_{35} \mathrm{Cl}_{3} \mathrm{O}_{3} \mathrm{SSn}$ & $\mathrm{C}_{26} \mathrm{H}_{32} \mathrm{Cl}_{6} \mathrm{~N}_{2} \mathrm{O}_{2} \mathrm{Sn}$ & $\mathrm{C}_{28} \mathrm{H}_{52} \mathrm{Cl}_{4} \mathrm{O}_{6} \mathrm{Sn}_{2}$ \\
\hline Formula weight & 652.64 & 735.93 & 863.88 \\
\hline Crystal system & Orthorhombic & monoclinic & triclinic \\
\hline Space group & $P 2_{1} 2_{1} 2_{1}$ & $P 2_{1}$ & $P-1$ \\
\hline$a / \AA$ & $8.0424(6)$ & $8.2101(13)$ & $8.8045(10)$ \\
\hline$b / \AA$ & $10.3818(7)$ & $42.742(7)$ & $10.3430(12)$ \\
\hline$c / \AA$ & $35.337(3)$ & $9.4003(15)$ & $11.6693(14)$ \\
\hline$\alpha /\left(^{\circ}\right)$ & 90 & 90 & 66.019(2) \\
\hline$\beta /\left(^{\circ}\right)$ & 90 & $105.545(2)$ & $83.732(2)$ \\
\hline$\gamma /\left(^{\circ}\right)$ & 90 & 90 & $72.472(2)$ \\
\hline Volume $/ \AA^{3}$ & $2950.4(4)$ & $3178.0(9)$ & $925.75(19)$ \\
\hline$Z$ & 4 & 4 & 1 \\
\hline$D_{c} /\left(\mathrm{g} \cdot \mathrm{cm}^{-3}\right)$ & 1.469 & 1.538 & 1.550 \\
\hline$\mu / \mathrm{mm}^{-1}$ & 1.233 & 1.334 & 1.672 \\
\hline$F(000)$ & 1328 & 1480 & 436 \\
\hline Crystal size / mm & $0.32 \times 0.20 \times 0.02$ & $0.35 \times 0.30 \times 0.25$ & $0.38 \times 0.22 \times 0.04$ \\
\hline$\theta$ range $/\left(^{\circ}\right)$ & 2.04 to 26.00 & 1.91 to 26.00 & 2.25 to 26.00 \\
\hline Tot. reflections & 19018 & 24106 & 5848 \\
\hline Uniq. Reflections, $R_{\mathrm{int}}$ & $5800,0.0728$ & $12371,0.0245$ & $3596,0.0308$ \\
\hline Reflections with $I>2 \sigma(I)$ & 4420 & 11499 & 3338 \\
\hline GOF on $F^{2}$ & 0.981 & 1.099 & 1.122 \\
\hline Flack parameter & $-0.03(3)$ & $0.06(2)$ & \\
\hline$R$ indices $[/>2 \sigma(I)]$ & $R=0.0479, w R=0.0994$ & $R=0.0530, w R=0.1309$ & $R=0.0346, w R=0.0934$ \\
\hline$R$ indices (all data) & $R=0.0678, w R=0.1075$ & $R=0.0569, w R=0.1331$ & $R=0.0371, w R=0.0949$ \\
\hline$\Delta \rho_{\min }, \Delta \rho_{\max } /\left(\mathrm{e} \cdot \AA^{-3}\right)$ & $-0.323,0.568$ & $-1.757,0.875$ & $-0.558,0.783$ \\
\hline
\end{tabular}

v, $\left.\mathrm{cm}^{-1}\right)$ : IR (KBr): $1648(\mathrm{C}=0), 1222(\mathrm{C}-\mathrm{O}) .{ }^{1} \mathrm{H} \mathrm{NMR}\left(\mathrm{CDCl}_{3}, d\right.$, ppm): 0.77-2.04 (m, 40H, H-1+H-5 H-13), 2.83 (t, $J=7.5 \mathrm{~Hz}$, $\left.J\left({ }^{119 / 117} \mathrm{Sn}-{ }^{1} \mathrm{H}\right)=194 / 188 \mathrm{~Hz}, 4 \mathrm{H}, \mathrm{H}-2\right), 3.79\left(\mathrm{~s}, J\left({ }^{119 / 117} \mathrm{Sn}-{ }^{-1} \mathrm{H}\right)=\right.$ $38 \mathrm{~Hz}, 6 \mathrm{H}, \mathrm{OCH}_{3}$ ), 5.07 (dt, $\left.J=4.5,11.0 \mathrm{~Hz}, 2 \mathrm{H}, \mathrm{H}-4\right) .{ }^{13} \mathrm{C}$ NMR (CDCl $\left.{ }_{3}, d, \mathrm{ppm}\right): 26.43$ (C-1), 28.17 (C-2), 182.14 (C-3), 81.71 (C-4), 46.90 (C-5), 23.34 (C-6), 33.97 (C-7), 31.41 (C-8), 40.41 (C-9), 20.72 (C-10), 26.40 (C-11), 21.92 (C-12), 16.42 (C-13), $52.35\left(\mathrm{CH}_{3} \mathrm{O}\right) .{ }^{119} \mathrm{Sn} \mathrm{NMR}\left(\mathrm{CDCl}_{3}, d, \mathrm{ppm}\right):-364.5$.

\section{Crystal structure determination}

The colorless singlecrystals of the complexes were obtained from chloroform or methanol by slow evaporation at room temperature. The intensity data were measured at 295(2) K on a Bruker Smart Apex area-detector fitted with graphite monochromatized Mo-K $\alpha$ radiation ( $0.71073 \AA$ ) using the $\phi$ and $\omega$ scan technique. The structure was solved by direct method and refined by a full-matrix least squares procedure based on $F^{2}$ using the SHELXL-97 (Sheldrick, 2008). The non-hydrogen atoms were refined anisotropically, and hydrogen atoms were placed at calculated positions. In the complex 4, the menthyl (C(4)-C(13)) is disordered over two conformations. The site occupancies were refined to $0.517(4): 0.483(4)$. In refinements, the C-C bonds and 1,3-distances of the disorderly menthyl were restrained to 1.52(1) and 2.50(2) A, respectively. The crystallographic parameters and refinements are summarized in Table 2. Crystallographic data have been deposited with the Cambridge Crystallographic Data Centre as supplementary publication numbers CCDC 1856984-1856986.

Acknowledgments: This work was supported by the Experimental Teaching Reform Project of Qufu Normal University (sj201401), the Undergraduate Innovation Project in Qufu Normal University (201710446040), and Shandong Provincial Natural Science Foundation, China (ZR2013BM007).

\section{References}

Airapetyan D.V., Petrosyan V.S., Gruener S.V., Korlyukov A.A., Arkhipov D E., Bowden A.A., et al., Structure of hypercoordinated monoorganodihalostannanes in solutions and in the solid state: the halogen effect. Inorg. Chim. Acta, 2015, 432, 142-148.

Balasubramanian R., Chohan Z.H., Doidge-Harrison S.M.S.V., Howie R.A., Wardell J.L., Some further studies of estertin compounds: crystal structures of $\left[\mathrm{NEt}_{4}\right]\left[\mathrm{MeO}_{2} \mathrm{CCH}_{2} \mathrm{CH}_{2} \mathrm{Sn}(\mathrm{dmio})_{2}\right]$ 
(dmio =1,3-dithiole-2-one-4,5-dithiolato) and $\left(\mathrm{MeO}_{2} \mathrm{CCH}_{2} \mathrm{CH}_{2}\right)_{2} \mathrm{SnX}$ $\left[\mathrm{X}_{2}=\mathrm{I}_{2},(\mathrm{NCS})_{2}\right.$ or $\left.\mathrm{Cl}, \mathrm{Br}\right]$. Polyhedron, 1997, 16, 4283-4295.

Buchanan H., Howie R.A., Khan A., Spencer G.M., Wardell J.L., Preparations and crystal structures of $\mathrm{Sn}\left(\mathrm{CH}_{2} \mathrm{CH}_{2} \mathrm{CO}_{2} \mathrm{Me}\right)_{2}\left(\mathrm{C}_{3} \mathrm{~S}_{5}\right)$ and $[\mathrm{Q}]\left[\mathrm{Sn}\left(\mathrm{CH}_{2} \mathrm{CH}_{2} \mathrm{CO}_{2} \mathrm{Me}\right)\left(\mathrm{C}_{3} \mathrm{~S}_{5}\right)_{2}\right]\left(\mathrm{Q}=\mathrm{NEt}_{4}\right.$ or 1,4-dimethylpyridinium, $\mathrm{C}_{3} \mathrm{~S}_{5}=4,5$-disulfanyl-1,3-dithiole-2-thionate). J. Chem. Soc., Dalton Trans, 1996, 541-548.

Chandrasekar S., Balachandran V., Evans H.-S., Latha A., Synthesis, crystal structures HOMO-LUMO analysis and DFT calculation of new complexes of p-substituted dibenzyltin chlorides and 1,10-phenanthroline. Spectrochim. Acta A, 2015, 143, 136-146.

Davies A.G., Organotin Chemistry (2nd ed.). Wiley-VCH, Weinheim, 2004, P174. DOI:10.1002/9780470758090

de Morais B.P., Donnici C.L., Rodrigues B.L., de Lima G.M., Wardell J.L., Bitzer R.S., Transesterification reactions of dimethoxycarbonylethyltin pyrrolidinodithiocarbamate, [Sn(PDTC $)_{2}\left(\mathrm{CH}_{2} \mathrm{CH}_{2} \mathrm{COOCH}_{3}\right)_{2}$ ], spectroscopic and X-ray structural characterization of new estertin dithiocarbamate complexes. J. Organometal. Chem., 2017, 832, 57-65.

Fuller A.L., Aitken R.A., Ryan B.M., Slawin A.M.Z., Woollins J.D., The X-Ray Structures of Sulfoxides. J. Chem. Crystallogr., 2009, 39, 407-415.

Garad M.V., Gopinathan M.S., Gopinathan C., Molecular addition complexes of $\beta$-carbalkoxyethyltin chlorides. Indian J. Chem., 1981, 20A, 412-414.

Glowka M.L., Martynowski D., Kozaowska K., Stacking of six-membered aromatic rings in crystals. J. Mol. Struct., 1999, 474, 81-89.

Guo M., Lin Y., Yao Y., Tian L., The crystal structures of two 2-methoxycarbonylethyltin trichloride adducts. Main Group Met. Chem., 2017, 40, 101-104.

Hall V.J., Tiekink E.R.T., Benzyltriehloro(1,10-phenanthroline-N,N') tin(IV) benzene solvate. Acta Crystallogr. C, 1996, 52, 2141-2143.

Harrison P.G., King T.J., Healy M.A., Structural studies in main group chemistry: Estertin derivatives, structural and spectroscopic studies. J. Organometal. Chem., 1979, 182, 17-36.

Holecek J., Nadvornik M., Handlir K., Lycka A., ${ }^{13} \mathrm{C}$ and ${ }^{119} \mathrm{Sn}$ NMR spectra of di-n-butyltin(IV) compounds. J. Organomet. Chem., 1986, 315, 299-308.

Howie R.A., Wardell S.M.S.V., (2-Carbomethoxyethyl)triiodotin at 120 K. Acta Crystallogr. E, 2002, 58, m220-m222.

Howie R.A., de Lima G.M., Wardell J.L., Wardell S.M.S.V., Harrison W.T.A., Solid state study of sulfoxide adducts of (2-amidoethylC,0)trihalostannanes: supramolecular networks constructed from hydrogen-bonds involving the amido units. J. Organometal. Chem., 2012, 716, 62-69.

Howie R.A., Harrison W.T.A., Lima G.M.D., Wardell J.L., Wardell S.M.S.V., Four distannoxane derivatives containing the bidentate 2-amidoethyl ligand. Z Kristallogr., 2011, 226,739-747.
Hutton R.E., Burley J.W., Oakes V., $\beta$-substituted alkyltin halides: I. Monoalkyltin trihalides: Synthetic, mechanistic and spectroscopic aspects. J. Organometal. Chem., 1978, 156, 369-382.

Lima G.M.D., Milne B.F., Pereira R.P., Rocco A.M., Skakle J.M.S., Travis A.J., et al., Experimental and ab initio structural study of estertin compounds, $\mathrm{X}_{3} \mathrm{SnCH}_{2} \mathrm{CH}_{2} \mathrm{CO}_{2} \mathrm{Me}$ : Crystal structures of $\mathrm{Cl}_{3} \mathrm{SnCH}_{2} \mathrm{CH}_{2} \mathrm{CO}_{2} \mathrm{Me}$ at $120 \mathrm{~K}$ and $\mathrm{Br}_{3} \mathrm{SnCH}_{2} \mathrm{CH}_{2} \mathrm{CO}_{2} \mathrm{Me}$ at 120 and 291 K. J. Mol. Struct., 2009, 921, 244-250.

Liu Q., Shi X., Zhang C., Tian L., Synthesis and structure of [2-((L)-menthoxycarbonyl)ethyl]diphenyltin halides. Main Group Met. Chem., 2015, 38, 93-97.

Lu N., Chang W.-H., Wei R.-J., Fang Y.-C., Han T.-W., Wang G.-Q., et al., Pyridinium saccharinate salts as efficient recyclable acylation catalyst: a new bridge between heterogeneous and homogeneous catalysis. Tetrahedron, 2016, 72, 3468-3476.

Maughan D., Wardell J.L., Burley J.W., Lewis acidity of carboxyethyltin chlorides, $\mathrm{Cl}_{3} \mathrm{SnCH}_{2} \mathrm{CH}_{2} \mathrm{CO}_{2} \mathrm{R}$ and $\mathrm{Cl}_{2} \mathrm{Sn}\left(\mathrm{CH}_{2} \mathrm{CH}_{2} \mathrm{CO}_{2} \mathrm{R}\right)_{2}$. J. Organomet. Chem., 1981, 212, 59-70.

Sheldrick G.M., A short history of SHELX. Acta Crystallogr. A, 2008, 64, 112-122.

Sousa G.F.D., Sabino J.R., Vencato I., Filgueiras C.A.L., Ardisson J.D., Synthesis, structural and spectral studies of five- and six-coordinate adducts of organotin(IV) halides containing dibenzylsulfoxide (dbso) as ligand. J. Braz. Chem. Soc., 2009, 20, 1425-1433.

Tian L.-J., Sun Y.-X., Liu X.-J., Yang G.-M., Shang Z.-C., Synthesis and structural characterization of 2-(-)-menthoxycarbonylethyltin compounds. Polyhredron, 2005, 24, 2027-2034.

Tian L., Zhang S., Yao Y., Shi X., Synthesis and crystal structure of [2-(menthoxycarbonyl)ethyl]tris(8-quinolinato)tin. Main Group Met. Chem., 2016, 39, 209-212.

Tian L., Yao Y., Wang Y., Liu J., Synthesis, structure and property of diorganotin complexes with chiral N-(5-chlorosalicylidene) valinate ligand. J. Mol. Struct., 2018, 1156, 441-449.

Van Koten G., Noltes J.G., Novel chiral triorganotin halides. Stabilization of optically active tin centers by intramolecular coordination. J .Am. Chem. Soc., 1976, 98, 5393-5395.

Varga R.A., Silvestru C., Deleanu C., Synthesis, solution behaviour and $\mathrm{X}$-ray structures of [2-( $\left.\left.\mathrm{Me}_{2} \mathrm{NCH}_{2}\right) \mathrm{C}_{6} \mathrm{H}_{4}\right] \mathrm{SnCl}$ and [2- $\left(\mathrm{Me}_{2} \mathrm{NCH}_{2}\right)$ $\mathrm{C}_{6} \mathrm{H}_{4} \mathrm{SnCl}_{3} \cdot$ DMSO. Appl. Organometal. Chem., 2005, 19, 153-160.

Wang L., Chen M., Zhang P., Li W., Zhang J., Palladium/PC-Phoscatalyzed enantioselective arylation of general sulfenate anions: scope and synthetic applications. J. Am. Chem. Soc., 2018, 140, 3467-3473.

Wang P., Shu H., Zhu G., Zhou Z., Two dimensional nuclear magneitc resonance analysis of bis(2,2'-bipyriidne)(2,2'-bipyriidne4,4-dicarboxylic acid) rurthenium(II). Chinese J. Anal. Chem., 1999, 27, 1043-1046. 